\title{
EDITORIAL Fashion in haematology and wine
}

(c) The Author(s), under exclusive licence to Springer Nature Limited 2021

Bone Marrow Transplantation (2022) 57:14-16; https://doi.org/ 10.1038/s41409-021-01480-x

'I have the simplest of tastes. I am always satisfied with the best'.

Oscar Fingal O'Flahertie Wilde (known as Oscar Wilde), Irish poet/playwright. 1854-1900.

What makes things become fashionable? Is it because they are rare, expensive, determined by some celebrity, an effective advertising campaign or as Oscar says 'the best'? In some cases, it reflects a change in the zeitgeist (the spirit or mood of the time). I attended the American Society of Hematology's (ASH) annual meeting yearly from 1974 until the recent pandemic. The audience numbers increased over these years and at the last meeting I attended there were $>25,000$ attendees. Three things always struck me, firstly the paucity of African-American delegates, secondly the low numbers of communications about Sickle Cell Disease (SCD) and thirdly the small trickle of attendees on the last morning and at the business meeting. Although the organisers tried valiantly to increase attendances on the last morning it has only met with limited success. As in all organisations, of which I am aware, the business meeting continues to be sparsely attended.

When I asked Dr Michael Debaun, at the annual ASH meeting in 2016 about the medical care of adult patients with SCD he replied: 'it is a fair statement to say that most adults with this disease would say that they are not receiving optimal medical care' [1]. Although the reasons for the answer are complex, the situation has improved. However, there has been a noticeable change recently. SCD research in now more frequently funded and it is noteworthy that the numbers of papers reflecting new and exciting interventions in the treatment of this disease have markedly increased. This trend probably reflects a change in the zeitgeist. A recent paper from Singh et al [2] shows that people with SCD suffer more complications of SARS-Co-V- infection than age matched controls but that overall survival was the same so perhaps things are improving. DeBaun et al. [3] have also published guidelines for CNS disease in children and adults in 2020. The other good news is that on April 26th President Joe Biden proclaimed a broader effort to highlight racial disparities in maternal mortality rates in the U.S.

Another area in which change has occurred is 'clinical trials. Dr Barbara Bierer is quoted in ASH Clinical News in July 2021: 'First, there is the biological question of whether individuals who are racially and ethnically diverse will respond differently to products in terms of safety and the second-and likely the more important issue-is a question of equal access to clinical trials and health equity.' This clearly reflects a change in the zeitgeist.

The other noticeable observation is the continued huge numbers of research papers and communications about the diagnosis and treatment of Acute Myeloid Leukaemia (AML). This is a rare disease and, at the time of diagnosis, most people are over the age of 60 years. According to $\mathrm{Yi}$ et al. [4] it has a worse prognosis than pancreatic, lung, liver and oesophageal cancers. In spite of allogeneic HCT the majority of people with AML die from their disease. Yes, of course, AML like many cancers has a genetic basis, but SCD was the first 'molecular disease' over 50 years ago and, as yet, we still don't have a cheap, effective and widely acceptable treatment. So, diseases come in and out of fashion for various complex, psychological and cultural reasons.

Chronic Lymphocytic Leukaemia (CLL) is recognised as the commonest leukaemia in the western world yet in the ASH '50 Years in Hematology: Research that Revolutionized Patient Care' published in 2008, it is not even mentioned. Yes, the monoclonal antibody Rituximab is mentioned for the treatment of NonHodgkin Lymphoma but by 2020 Milne et al. [5] state: 'in the last two decades a rapid increase in treatment with small molecules have revolutionized the treatment of CLL'. This, surely, is another example of a new zeitgeist. There is no doubt we are living in the age of immunotherapy of malignant disease which hopefully will lead to cures, with minimal toxicity.

Another notable change has been the feminisation of medicine. Many medical schools are now reporting up to $70 \%$ of female undergraduates This is indeed a change from 50 years ago Fig. 1 and is to be welcomed. A note of caution however, as a French female Professor of Haematology said to me: 'If medicine becomes fully feminised then it will lose its social standing in the community'. This is a regrettable prediction and hopefully will not happen. Richter et al., writing recently in the New England Journal of Medicine [6] examined the question why women had a reduced rate of academic promotion compared to men. They concluded that over a 35-year period, women physicians in academic medical centres were less likely to be promoted to the rank of associate or full professor or to be appointed department chair, and there was no apparent narrowing of the gap over that time. They provided many credible explanations for this disparity, but one can't help thinking that misogyny plays a part.

Do fashions change in wine drinking? Most certainly, yes, whether due to a change of taste or clever marketing or both. Probably the best-known example in the wine world is Prosecco Fig. 2. As with many wines we are indebted to Gaius Plinius Secundus, better known as Pliny the Elder, who had opinions about many things including wine. In his 'Natural History', a series of 37 books, of which books 14 and 17 are devoted to wine and viticulture [7], he expresses some of those opinions. He was an early proponent of the importance of the soil over the vine variety! He recommended the wine 'Pucino', supposedly, a forerunner of Prosecco, for its medicinal properties (I'll drink to that). Most people, outside Italy, never heard of Prosecco until about 15 years ago but due to clever marketing it now is widely 


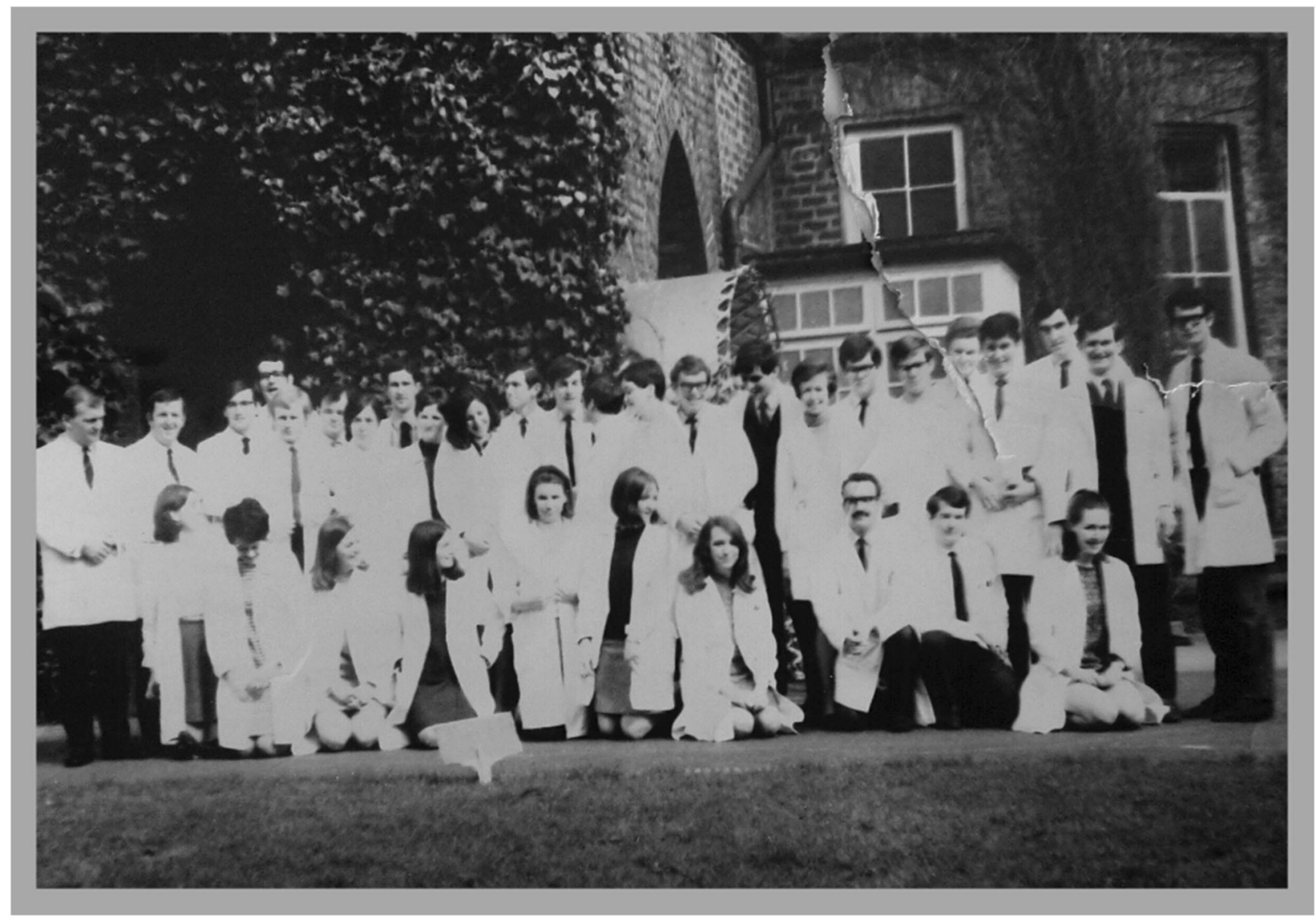

Fig. 1 Interns. Interns in St Vincent's Hospital, Dublin, Ireland. 1970.

consumed in the UK, USA, Germany and somewhat surprisingly the largest increase in sales has been in France.

How is Prosecco different from champagne? Firstly, the grape is Grela in Prosecco and a blend of Chardonnay, Pinot Noir and Pinot Meunier in champagne. Secondly, the secondary fermentation of Prosecco takes place in a tank as opposed to the bottle in champagne and thirdly, and probably most important of all, is the price. Prosecco is significantly cheaper than champagne. Prosecco can be sweet dry or very dry, depending on the amount of sugar added at the stage of secondary fermentation. The fashion now seems to be for dry sparkling wine. My own preference, when drinking Italian sparkling wine, is Franciacorta from Lombardy [8].

In the late 1970s and early 1980s, heavily oaked Chardonnay, especially from Australia was very fashionable Fig. 2. Now the taste has definitely changed to un-oaked or very lightly oaked Chardonnay, from whatever country. Likewise, heavily oaked Cabernet Sauvignon from California has now been replaced by lower alcohol, unoaked or lightly oaked wine.

I tasted my first glass of Albariño in the Arts Hotel in Barcelona about 30 years ago. This grape was probably brought by monks and pilgrims from the Abbey of Cluny in France and now the wine is made in Rias Baixas (pronounced bysis) in Galicia in Spain and Monção and Melaço in Portugal. It is now a very fashionable and widely consumed wine.

Vegan wine is surely one of the strangest wine fashions. Most good wines are fined with egg white but eschewed by vegans. Some vegans refuse to drink wines sealed with beeswax or labelled adhered with animal glue. I presume all the customers who frequent Daniel Humm's 3star restaurant in New York have bare feet or are wearing biodegradable, recyclable plastic shoes, without socks! I can't help thinking this is a marketing ploy.

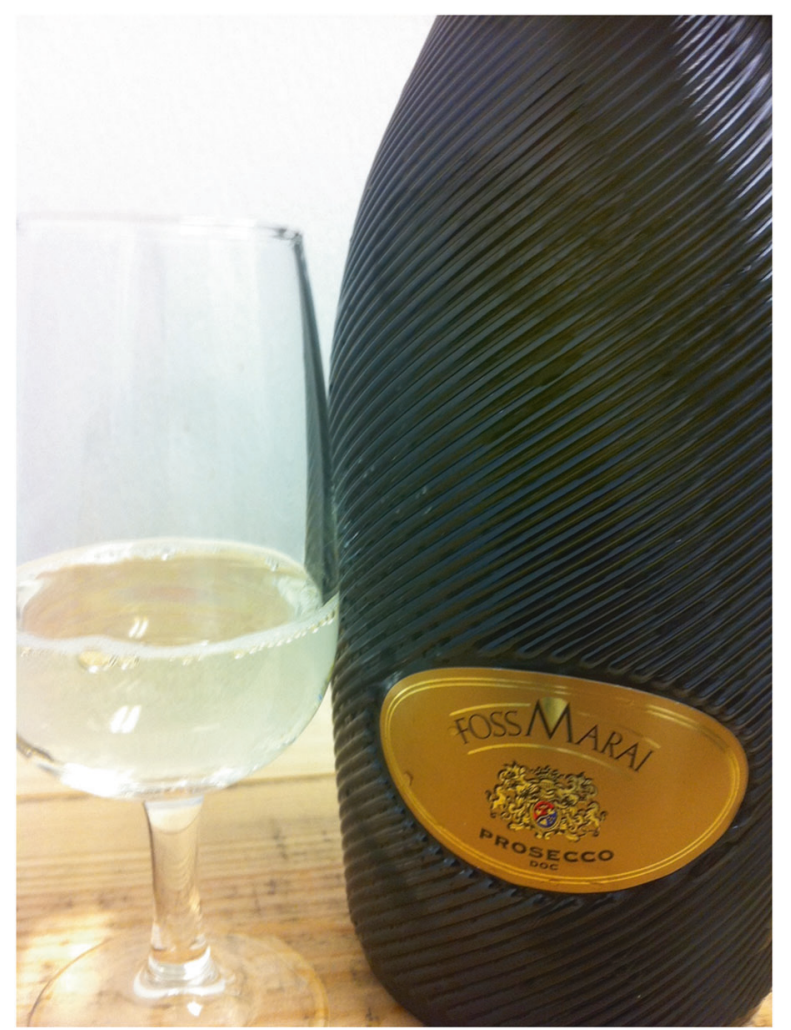

Fig. 2 Prosecco. A bottle of Prosecco. The wine can vary from sweet to very dry. 


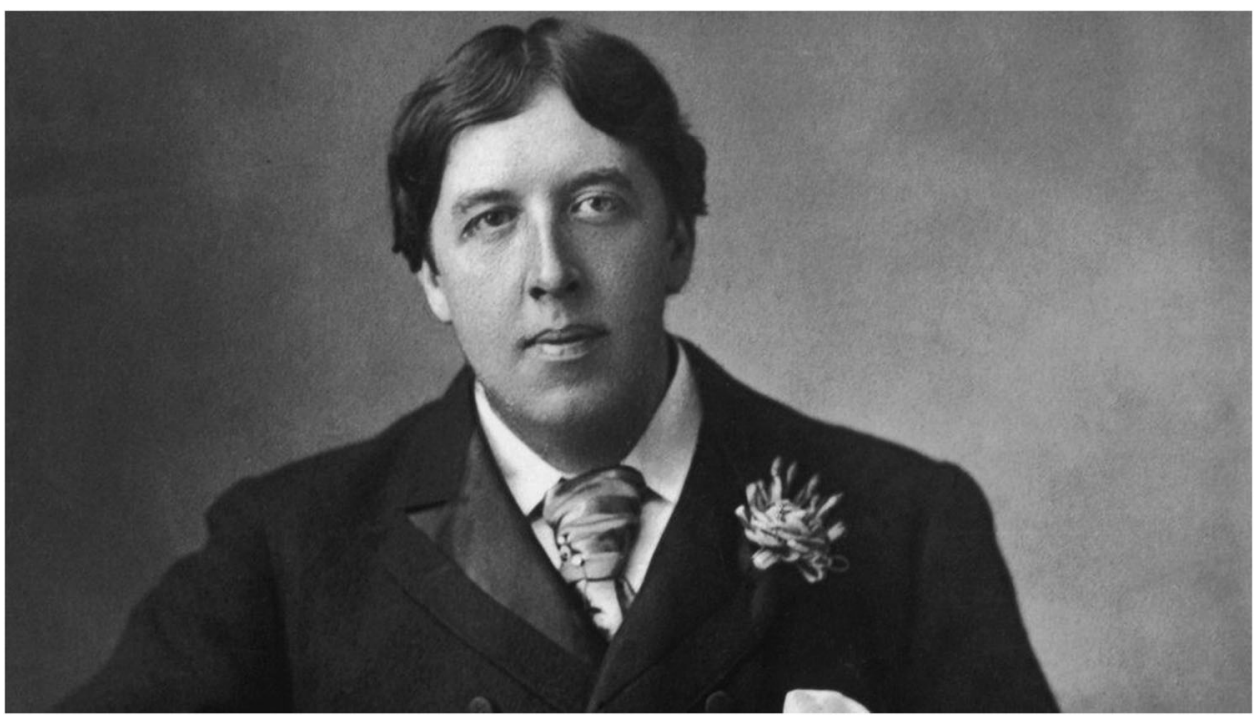

Fig. 3 Oscar Wilde. Oscar Fingal O'Flahertie Wilde, Irish poet/playwright.

Until quite recently the hand of the oenologist was felt to be very important, but now minimal interference with the vines is de rigueur and organic and biodynamic wine making are becoming fashionable. Without being too cynical, I can't help believing that this is also in part a marketing ploy. As you can see, I have steered clear of women's hem lines as this is an area fraught with difficulties. However, I am reminded again of Oscar Wilde's quip in his play, An Ideal Husband: 'Fashion is what one wears oneself. What is unfashionable is what other people wear' Fig. 3.

Whatever the fashion in wine drinking, you should drink what you enjoy. The rules are there to be broken and I tend to agree with Oscar Wilde; I have the simplest of tastes. I am always satisfied with the best'.

Of course, in answer to the question posed in 'Information overload in haematology and wine' published in August it was Petrarch (as he claimed) and he was reading St Augustine's confessions.

\section{Shaun R. McCann $\mathbb{1 D}^{1 凶}$ \\ ${ }^{1}$ Department of Haematology, Trinity College, Dublin, Ireland. email: shaunrmccann@gmail.com}

\section{REFERENCES}

1. McCann Shaun R. Blood matters. European Hematology Association (EHA). 2019. Interview with Dr Michael DeBaun, December 2016, Nashville, USA. ISBN 978-90823759-1-6

2. Singh A, Brandow AM, Panepinto JA. COVID-19 in individuals with sickle cell disease/trait compared with other black individuals. Blood Adv. 2021;5:1915-192. 10 1182/bloodadvances. 2020003741

3. DeBaun MR, Jordan LC, King AA, Schatz J, Vichinsky E, Fox CK, et al. ASH 2020 guidelines for sickle cell disease: prevention, diagnosis and treatment of cerebrovascular disease in children and adults. Blood Adv. 2020;4:1554-86.
4. Yi M, Li A, Zhou L, Chu Q, Song Y, Wu K. The global burden and attributable risk factor analysis of acute myeloid leukemia in 195 countries and territories from 1990 to 2017: estimates based on the global burden of disease study 2017. J Hematol Oncol. 2020;13:72 https://doi.org/10.1186/s13045-020-00908-z

5. Milne K, Sturrock B, Chevassut T. Chronic Lymphocytic Leukemia in 2020: the future has arrived. Curr Oncol Rep. 2020;22:36 https://doi.org/10.1007/s11912-0200893-0

6. Richter KP, Clark L, Wick JA, Cruvinel E, Durham D, Shaw $P$, et al. Women physicians and promotion in academic medicine. N Engl J Med. 2020;383:2148-57.

7. Pliny the Elder. Natural History: a Selection. Penguin Classics. John Healy (introduction, translator). Aug 1991. Penguin Books. London, UK.

8. McCann, Shaun R. Haemopoietic cell transplants, corneal transplants and champagne. Bone Marrow Transpl. 2019;10. https://doi.org/10.1038/s41409-019-0551-z.

\section{AUTHOR CONTRIBUTIONS}

Shaun McCann is solely responsible for writing and submitting this article.

\section{COMPETING INTERESTS}

The authors declare no competing interests.

\section{ADDITIONAL INFORMATION}

Correspondence and requests for materials should be addressed to Shaun $\mathrm{R}$. McCann.

Reprints and permission information is available at http://www.nature.com/ reprints

Publisher's note Springer Nature remains neutral with regard to jurisdictional claims in published maps and institutional affiliations. 